\title{
Legal Hermeneutics in the Preparation of A Case in the Province of Bali
}

\author{
Astariyani ${ }^{1}$, Sudiarta ${ }^{2}$, Diah WPD ${ }^{3}$ \\ Faculty of Law, Udayana University \\ Denpasar, Bali \\ astariyani99@yahoo.com \\ luh astariyani@unud.ac.id
}

\begin{abstract}
The purpose of this study intends to examine the legal politics of the formation of laws and regulations, especially regional law products that are focused on the formation of a case based on legal research methods and hermeneutic approaches. The formation of Perkada, which is based on hermeneutics in the form of interpretation, requires carefulness so as not to cause problems in the form of conflict norms or fuzzy norms. Based on these objectives a research question was proposed as a guide in examining the above issues, namely: 1) Basic application of legal hermeneutics; and2) Form of application in the formation of Perkada in Bali Province. The final result expected from this research is to obtain information, understanding, and study in the framework of the preparation of the laws and regulations, especially the drafting of regional law products, namely in the Province of Bali.
\end{abstract}

Keywords: Hermeneutics and Perkada

\section{BACKGROUND}

Delegation of authority means delegation of authority in which the authorized party (delegates) will exercise it on its own responsibility. ${ }^{1}$ Article 246 paragraph (1) of Act Number 23 of 2014 on Regional Government as amended several times and lastly by Act Number 9 of 2015 on the Second Amendment to Act Number 23 of 2014 on Regional Government, stipulates that in order to implement the Regional Regulation or over the power of Laws and Regulations, the Head of Region shall establishes the Head of Region Regulation. The meaning of the Head of Regional Regulation shall be stipulated in Article 1 number 26 of Regional Government Act which further refers to the Head of Region Regulation as Governor Regulation and Regent or Mayoral Regulation.

Article 18 paragraph (6) of the 1945 Constitution of the State of the Republic of Indonesia (hereinafter referred to as the 1945 Indonesian Constitution), which constitutes as the relevant provision to the establishment of Laws and Regulations, states that, "Regional Government shall

${ }^{1}$ C. Van Der Vlies, 2005, Buku Pegangan Perancang Peraturan Perundang-undangan (Handboek Wetgeving), Direktorat Jenderal Peraturan Perundang-undangan Departemen Hukum dan Hak Asasi Manusia RI, p. 80. have the right to establish Regional Regulation and other Regulations to implement its autonomy and assistance tasks". The provision on the hierarchy of Laws and Regulations can be found in Article 7 of Act Number 12 of 2011 on the Establishment of Laws and Regulations, as for the Laws and Regulations outside the hierarchy can be found in Article 8 of such Act. Article 7 paragraph (1) regulates the type and hierarchy Laws and Regulations which consists of:

a. 1945 Indonesian Constitution;

b. Decree of the People's Consultative Assembly;

c. Act/Government Regulation in Lieu of Act;

d. Government Regulations;

e. Presidential Decree;

f. Provincial Regional Regulations; and

g. Regency/City Regional Regulations.

Laws and Regulations outside the hierarchy are provided for in Article 8 paragraphs (1) and (2). Article 8 paragraph (2) of Act Number 12 of 2011 on the Establishment of Laws and Regulations stipulates that:

"(2) The existence of Laws and Regulations as referred to in paragraph (1) are recognized and have binding legal force to the extent commanded by higher Laws and Regulations or established by virtue of authority." 
Therefore in order to have binding legal force, such Laws and Regulations shall meet the following element under the above provision of Article 8 paragraph (2), namely:

1. commanded by higher Laws and Regulations; or

2. established by virtue of authority.

The elucidation of Article 8 paragraph (2) states that the meaning of "by virtue of authority" is the administration of certain government affairs in accordance with the provisions of Laws and Regulations. Delegation of regulation to Governor Regulation can be found in Article 246 paragraph (1) of Act Number 23 of 2014 on Regional Government which determines that in order to implement the Regional Regulation or over the power of Laws and Regulations, the Head of Region shall stipulate Head of Region Regulation. This provision indicates that the functions of the Governor Regulation are to:

a. implement Regional Regulation; and

b. implement the power of Laws and Regulations.

The wording of "to implement" has some meanings: (1) there is a strict command and (2) without strict command, however, the substance requires implementation rules. In the Law Dictionary the wording "over the power" means power granted to perform an act on behalf of the authorizer, ${ }^{2}$ which actually indicates further elaboration of the higher Laws and Regulations and the substance shall be regulated under the Regional Regulation. The wordings of "to implement" and "over the power" contain ambiguity of command and uncertainty on the substance in relation to the implementation. Substance-related to the regional autonomy and assistance task is not justified to be delegated. Such understanding shows further elaboration of the higher Laws and Regulations. From the wordings of "to implement" and "over the power" it is noted that the existence of such command would provide an opportunity for a Governor Regulation to be established without any command, since in the delegation of regulation there shall be a command so that the scope of the regulated material and the Laws and Regulations are clear; and vagueness concerning the substance on the implementation of regional autonomy which is not justified to be delegated, but shall be regulated in the Regional Regulation. Based on the Layers of Legal Science proposed by J. Gijssels and Marck Van Hoecke which contains legal philosophy, legal theory and legal dogmatic, ${ }^{3}$ the vague legal norms contained in Article 246 paragraph (1) of Act Number 23 of 2014 on Regional Government appears that the delegation of authority to regulate is problematic.

The philosophical problem that arises in relation to the formation of Laws and Regulations,

\footnotetext{
2 Charlie Rudayat, 2014, Kamus Hukum, Pustaka Mahardika, Bandung, p. 284.

J.J.H. Bruggink, 1996, Refleksi Tentang Hukum, Citra Adytia Bhakti, Bandung, p.170-172.
}

seen from the opinion of Gustav Radbruch, is belong to theism which connecting the dualism of das sein and das sollen by constructing the third scope which is culture die kultur that lies between the natural reality and the atmosphere of absolute values that cannot limited by time. ${ }^{4}$ SatjiptoRaharjo relying on the view Gustav Radbruch revealed that validity is the validity of the law and its relation to the basic values of the law. The law is required to fulfill various works which according to Radbruch is referred to as the basic values of law namely justice, utility (zweckmaszigkeit), and legal certainty. ${ }^{5}$ By using the recognition in justice approach, Anthony D'Amato is easier to find the injustice rather than to explain what is justice in order to find the meaning of justice and not a question of what is justice but who suffers because of such injustice. ${ }^{6}$

Theoretical problems are examined from the opinion of I.C Van Der Vlies. There are two sources of the Laws and Regulations establishment authority, namely: attribution and delegation. ${ }^{7}$ Delegation of regulation to Governor Regulation based on Article 8 paragraph (2) of Act Number 12 of 2011 on the Establishment of Laws and Regulations requires "... has binding legal force as long as it is commanded by higher Laws and Regulations or established by virtue of authority." It is shall be commanded by the higher Laws and Regulations indicates the need for delegation. The meaning of it shall be established by virtue of authority, based on the Elucidation of Article 8 paragraph (2) of Act Number 12 of 2011 on the Establishment of Laws and Regulations, is to perform administration of certain governmental affairs in accordance with the provisions of the Laws and Regulations. Those two meanings require the existence of a delegation of authority to regulate. A theoretical problem arises when there is a circumstance in which a substance must be governed in the form of a Governor Regulation but there is no delegation of regulation. Another theoretical problem arises when the substance of a Governor Regulation is not a substance within the framework of the delegation, however, such substance is still stipulated in the form of Governor Regulation. The theoretical problem related to the delegation of authority to regulate in the Government Regulation happens when there is an establishment of Governor Regulation which contains the substance to implement the attribution authority meanwhile it is noted from the above explanation that the establishment of Government Regulation is based on the delegation authority.

\footnotetext{
${ }^{4}$ Theo Huijbers, 1982, Filsafat Hukum Dalam Lintasan Sejarah, Yayasan Kanisius Yogyakarta, p. 161.

${ }^{5}$ Satjipto Raharjo, 2000, Ilmu Hukum, Citra Aditya Bakti, Bandung, h. 19

${ }^{6}$ Philipus M Hadjon \& Tatiek Sri Djatmiati, 2014, Argumentasi Hukum, Gadjah Mada University Press, p. 96.

${ }^{7}$ I.C Van Der Vlies, Op.Cit, p..80
} 
The sociological problem is the inability of the legislature to predict which of which dynamics of society that needs to be regulated under the law when the delegation was born. Therefore, the Laws and Regulations output is often not in time to follow the development of society. Hence, the legislature delegates some of its legislative authority to the executive body so that the executive body also establishes Laws and Regulations. ${ }^{8}$ This is a revolutionary development of Trias Politica theory from Montesquieu which places the government as the only executor (command) of the Acts. ${ }^{9}$ In its development, the delegation of authority to regulate does not only exist from the legislature to the executive but also from the legislature to the legislature. This development is apparent in the provision of Article 8 paragraph (1) of the Act on the Establishment of Laws and Regulations. This article stipulates that in addition to the delegation the authority to regulate from the legislature to the executive there is also such delegation from the legislature to the legislature. The development of such delegation of authority to regulate can be seen in the establishment of the House of Representative Regulation and the Regional Representative Council Regulation.

The legal dogmatic problem is examined from the provision concerning the delegation of authority to regulate in Article 64 of Act Number 12 of 2011 on the Establishment of Laws and Regulation. Such article stipulates that the provisions on the drafting techniques of Laws and Regulations as referred to in paragraph (1) are listed in Appendix II which is an inseparable part of this Act. Delegation of authority to regulate can be found in number 198 and number 200 of Appendix II from Act Number 12 of 2011 on the Establishment of Laws and Regulations.

Problem-related to the establishment of Governor Regulation appears at the time when the formulation of legal norms in such regulation is not based on a Regional Regulation and is not based on the power of the higher Laws and Regulations. Governor Regulation of Bali No. 31 of 2014 on Public Service Implementation can be said as one example of the Governor Regulation that is established without delegation of authority to regulate to the Governor Regulation. Delegation of regulation to the Governor Regulation indicates the existence of vagueness or vague norm which can be seen in Article 246 of Act Number 23 of 2014 on Regional Government related to the meaning "to implement the Regional Regulation or over the power Laws and Regulations". Based on the existence of such vague, thus it becomes relevant to study these problems which result is presented in this

${ }^{8}$ P.P.Craig, 1994, Administrative Law, London Sweet and Maxwell, p. 245.

9 Max BoliSabon, 1994, Ilmu Negara BukuPanduanMahasiswa, GramediaPustakaUtama, p.169. dissertation entitled "Delegation of Regulation to Governor in Ensuring Utility and Justice".The legal issues raised based on the above-explained background are:

1. The philosophical basis related to the need for delegation of regulation.

2. Regulation direction to the Governor Regulation in the Regional Regulation Act and the Establishment of the Laws and Regulations Act.

3. The process of establishing Governor Regulation which is based on the delegation of Laws and Regulations.

This research is generally aimed at the development of legal science, especially for governmental law concentration which related to the Delegation of Regulation to Governor Regulation in Ensuring Utility and Justice.

In addition to the general purpose, this research also specifically aims to:

1. Examine philosophically about the need for delegations of authority to regulate.

2. Examine and find the direction of regulation in the Delegation of Regulation to Governor Regulation in Ensuring Utility and Justice.

3. Examine the process and find patterns of the Governor Regulation establishment based on the delegation of authority to regulate.

This research is expected to have:

1) Theoretical benefit, this research is expected to contribute to the development of legal science, especially the development of legal science in the field of Regional Legislation.

2) Practical benefit, it is hoped that this research will contribute to the competent parties in relation to the direction for the Governor Regulation.

3) Benefit for the researchers, this research is expected to provide a deeper understanding of legal science, especially related to the Laws and Regulations science.

During the tracing process, there are some similar studies with this research, however, the essence is still different. The previous dissertation research results are as follow: 1). Dissertation research entitled Development of Laws Formation in Indonesia by Bayu Dwi Anggono from UI Doctoral Program of $2014 ;^{10}$ 2) Dissertation research entitled Authority to Revoke Regional Regulation by Sukardi from UNAIR Doctoral Program of $2009 ;{ }^{11}$ 3) Dissertation research entitled The Hierarchy of Law Regulation in Indonesia by Febrian from UNAIR Doctoral Program of $2004 ;^{12}$ 4) Dissertation research

${ }^{10}$ Bayu Dwi Anggono, 2014, Disertasi: Perkembangan Pembentukan Undang-Undang di Indonesia, Universitas Indonesia, Jakarta.

${ }^{11}$ Sukardi, 2009, Wewenang pembatalan Perda by Sukardi from Program Doktor UNAIR Surabaya

${ }^{12}$ Febrian, 2004, Disertasi: Hierarki Aturan Hukum di Indonesia, Universitas Airlangga, Surabaya. 
entitled The Existence of Policy Regulation in the Planning and Implementation of Development Plan in Region and Its Impact on the Development of Written Law by Marcus Lukman from UNPAD Doctoral Program of $1996 ;{ }^{13}$ 5) Dissertation research entitled Policy Implementation of the Delegation of Authority from the Regent to the District Head for the Development of Regional Autonomy and Population (Study on the Delegation of Authority from the Regent to the District Head in Bandung Regency) by Andi Pitono from IH UNPAD Doctoral Program of $2011 ;{ }^{14}$ 6) Dissertation research entitled Discretion \& Government Responsibility by Ridwan from UNAIR Doctoral Program 2014. ${ }^{15}$

\section{MATERIAL AND METHOD}

This research is normative legal research. ${ }^{16}$ This study uses normative legal research because it started from the existence of vague and non-synchronized norms.

This research uses statute, philosophical, theoretical, conceptual approaches by reviewing the views on delegation.

This research uses the sources of primary legal material, secondary legal materials which are documents or legal materials that support primary legal material such as research results that have any relevance to the research.

The legal materials are collected by conducting a documentary study in which such primary, secondary and tertiary legal materials are also supported by interviews. Interviews are conducted on informants who related to the establishment of the Governor Regulation.

The technical analyses of the legal materials used in this research are the description, interpretation, systematization, argumentation and evaluation techniques. At the description stage, exposure and determination of the meaning of the studied-rules of the laws are conducted. With regard to the research on delegation of regulation to the Governor Regulation, the authentic, grammatical and hermeneutical interpretations are used.

${ }^{13}$ Marcus Lukman, 1996, Disertasi: Eksistensi Peraturan Kebijaksanaan Dalam Bidang Perencanaan an Pelaksanaan Rencana Pembangunan Di Daerah Serta Dampaknya Terhadap Pembangunan Hukum tertulis, Unpad, Bandung.

Andi Pitono, 2011, Disertasi: Implementasi Kebijakan Pendelegasian Wewenang Dari Bupati Kepada Camat Bidang Pengembangan Otonomi Daerah Dan Kependudukan (Studi Tentang Pendelegasian Wewenang Dari Bupati Kepada Camat Di Kabupaten Bandung), Universitas Airlangga, Surabaya.

15 Ridwan, 2013, Diskresi \& Tanggung Jawab Pemerintah, Universitas Airlangga, Surabaya.

${ }^{16}$ Jan Gijsels, Mark Van Hocke (terjemahan B. Arief Sidharta) Apakah Teori Hukum Itu ?, Laboratorium Hukum Universitas Parahyangan Bandung, p. 109-110.

\section{RESULT}

a. The Establishment of Governor Regulation Based on Interpretation of Laws and Regulations

According to Gadamer, understanding of something is to interpret something, and vice versa. ${ }^{17}$ Hermeneutic had a major influence especially on the theory of legal discovery (rechtsvindings theorie) in the seventies, especially by German theorists Jozef Esser and Karl Larenz. In the Netherlands, the hermeneutic of H.G. Gadamer was introduced into the theory of legal discovery by J.B.M. Vranken. The formulated hermeneutical argument is as follow: dat men feiten moet kwalificeren in het licht van de normen en de normen moet interpreter in het licht van de feiten behoort tot het paradigm van de huidigerechts vindings theorie ${ }^{18}$ - that one must qualify facts in the light of the rules and interpret the rules in the light of facts. Etymologically, the word hermeneutic comes from the English word hermeneutic and hermeneutics. The first (hermeneutic) is adjective which means 'interpretation' and the second (hermeneutics) has three meanings, namely:

1. Science of interpretation;

2. Science to know the intentions contained in the words and expressions of the author;

3. An interpretation that specifically refers to the interpretation of a text or scripture. ${ }^{19}$

Hermeneutics is derived from the derivation of the noun "hermeneia" (Greek) which can literally be interpreted as 'interpretation'. ${ }^{20}$

Based on Article 8 Paragraph (2) of Act Number 12 of 2011 on the Establishment of Laws and Regulations, it is noted that "The existence of Laws and Regulations as referred to in paragraph (1) are recognized and have binding legal force to the extent commanded by higher Laws and Regulations or established by virtue of authority." The norm of this article indicates that Governor Regulation is also included in the legislation in question.

In accordance with such opinion, RahadiZakaria from the Fraction of PDIP in the Minutes of Discussion also states that" ...its only regulate issues that are very technical, not politically or juridical different from Government Regulation in Lieu of Law, Government Regulations and others. The practice so far shows, related to the Governor Regulation and Regent Regulation, for example, it is just because of the authority of the Governor and Regent which are elected then it has considerable authority, I think this is not necessary to be in the regulatory areas which are in a technical level". ${ }^{21}$

\footnotetext{
${ }^{17}$ Ibid, p.96.

${ }^{18}$ J.J.H. Bruggink, op. cit.,p. 139.

${ }^{19}$ JazimHamidi, 2005, Hermeneutika Hukum: Teori Penemuan Hukum Baru dengan Interpretasi Teks, UII Press, Yogyakarta, p.19.

${ }^{20}$ Ibid,p. 20 .

${ }^{21}$ Ibid, p. 17
} 
The discussion in the minutes indicates that the establishment of Governor Regulation can be based on the authority shown in the form of execution of duties as a form of governor's authority in establishing Government Regulation based on the delegation of authority and of mandatory authority in his/her position as the Governor.

Based on the authentic interpretation of the Elucidation of Article 12 and Article 13 of Act Number 12 of 2011 on the Establishment of Laws and Regulations, such article is interpreted as a command or commanded whether expressly or not expressly. It means that it has the substance of the explicit and implicit Laws and Regulations delegations.

Governor Regulation as commanded by the higher Laws and Regulations means that such Governor Regulation can be established whether because it is expressly or not expressly commanded. Thus, the characters of this Governor Regulation are explicit and implicit Laws and Regulations delegation. In terms of vertical and horizontal delegations, the delegation of authority to regulate to Governor Regulation in Article 8 paragraph (1) of Act 12/2011 adopts a pattern of the vertical delegation of regulation. Governor Regulation is one type of Laws and Regulations based on Article 8 Paragraph (1) of Act Number 12 of 2011 on the Establishment of Laws and Regulations as mentioned above as the bestuur unit in the implementation of Regional Regulation and governance affairs as provided in Act Number 23 of 2014 on Regional Government.

The word "command or commanded" is interpreted into as expressed or non expressly command or commanded as previously described.
Governor Regulation shall be established pursuant to the authority of Article 8 paragraph (1) of Act Number 12 of 2011 on the Establishment of Laws and Regulations and are included in the category of non expressly commanded or command. This means that the implicit Laws and Regulations delegation is adopted.

\section{DISCUSSION}

With regard to Article 17 paragraph (1) of Act Number 23 of 2014 on Regional Government, "Regional policy" means Regional Regulation, Head of Region Regulation and Head of Region Decision. The phrase "administering the governmental affairs under Regional authority" refers to governmental affairs which are part of the regional authority as defined in Article 15 paragraph (1) of Act Number 23 of 2014 on Regional Government. It determines the distributions of concurrent governmental affairs between the Central Government and Provincial Region and Regencies/Municipalities Region are listed in the Appendix which is an integral part of this Act. Such governmental affairs under the regional authority shall be governed by or within the Governor Regulation. In accordance with Article 17 paragraph (1) of Act Number 23 of 2014 on Regional Government, the choice among Provincial Regulation, Governor Regulation, and Governor Decision as the regulatory instrument of governmental affairs in the area of Regional Government's interpretation to use whether one or all three as needed. Bali Provincial Government is understood to interpret the interpretation of the legislation as shown in the table below.

Table 1.Governor Regulation Established Based on the Interpretation of Laws and Regulations

\begin{tabular}{|l|l|l|l|l|}
\hline Governor Regulation & \multicolumn{1}{|c|}{$\begin{array}{c}\text { Laws and } \\
\text { Regulations }\end{array}$} & $\begin{array}{c}\text { Law No.23 of } \\
2014\end{array}$ & $\begin{array}{c}\text { Regional } \\
\text { Regulation }\end{array}$ & \multicolumn{1}{|c|}{ Analyses } \\
\hline $\begin{array}{l}\text { Governor Regulation } \\
\text { of Bali No. 5 of 2013 } \\
\text { on the Disaster } \\
\text { Management }\end{array}$ & $\begin{array}{l}\text { Article 6 } \\
\text { paragraph (4) of } \\
\text { Government } \\
\text { Regulation No. 21 } \\
\text { of 2008 on the } \\
\text { Implementation of } \\
\text { the Disaster } \\
\text { Management }\end{array}$ & $\begin{array}{l}\text { Attachment E } \\
\text { of 2014 No. 23 }\end{array}$ & & $\begin{array}{l}\text { Government Regulation } \\
\text { No. 21 of 2008 does not } \\
\text { regulate any delegation of } \\
\text { authority to Governor } \\
\text { Regulation }\end{array}$ \\
\hline $\begin{array}{l}\text { Governor Regulation } \\
\text { of Bali No. 34 of 2014 } \\
\text { on the Implementation } \\
\text { of Public Services }\end{array}$ & $\begin{array}{l}\text { Act No. 25 of } \\
\text { 2009 on Public }\end{array}$ & $\begin{array}{l}\text { Article 344 } \\
\text { pervices } \\
\text { of Lagraph (1) No. 23 } \\
\text { of 2014 }\end{array}$ & & $\begin{array}{l}\text { There is no delegation of } \\
\text { authority of the Governor } \\
\text { regulation establishment in } \\
\text { Act No. 25 of 2009 on }\end{array}$ \\
\hline
\end{tabular}




\section{CONCLUSIONS}

a. Conclusions

Based on the above analyses and discussions upon the three raised legal issues, there are three conclusions as follow:

1) The philosophical basis of the delegation of regulation are as follow:

a. the legislators cannot formulate technical or detail norms in accordance with the needs of social development in the establishment of Laws and Regulations;

b. the establishment of Laws and Regulations that is based on the delegation authority is more technical in relation to the regulated content;

c. the existence of urgency factor and relatively long discussions in the legislature level which are in contrast to Laws and Regulations which are established by the delegation of regulation which is much faster.

d. in the delegation of regulation, there is the existence of elasticity factor to make changes in Laws and Regulations so that the utility and justice can be achieved.

2) The direction of the delegation of regulation to the Governor Regulation can be seen from 2 (two) directions of regulation, namely:

b. The direction of regulation in the Regional Government Act is stipulated in Article 246 paragraph (1). It stipulates that in order to implement the Regional Regulation or over the power of Laws and Regulations, the Head of Region shall establish Head of Region Regulation. Based on this Article, it is necessary to understand two meanings of the legal norms namely: "to implement" and "over the power".

c. The direction of regulation in Article 8 paragraph (2) of Act on the Establishment of Laws and Regulation. It regulates the establishment of Laws and Regulations and states that have binding power as legislation as long as commanded by the higher Laws and Regulations or established by authority. The direction of regulation is also regulated in number 198 to 216 of the Attachment II of Act Number 12 of 2011 on the Establishment of Laws and Regulations.

3) The process of establishing a Governor Regulation that guarantees utility and justice is based on the provisions of Article 246 paragraph (1) of Act Number 23 of 2014 on Regional Government. It is determined that in order to implement the Regional Regulation or over the power of Laws and Regulations, the Head of Region establishes Head of Region Regulation. Such understanding indicates: first, a delegation of regulation to Governor Regulation in the form of implementing Regional Regulation; second, a delegation of regulation to Governor Regulation in the form of over the power of Laws and Regulations; and three, regulation which is interpreted and implemented by the Governor through the establishment of Governor Regulation. The study related to the establishment of Governor Regulation based on the Laws and Regulations delegation by reviewing the governance and legal hermeneutics as Governor Regulation that is established on the interpretation of Laws and Regulations to achieve utility and justice.

\section{b. Suggestions}

Based on the discussions and conclusions as explained above, the proposed suggestions are as follow:

1) In relation to the meaning of "implement" and "over the power", the word "implement" should be understood as the explicit and implicit command, meanwhile "over the power" should be understood as an explicit command;

2) With regard to the Governor Regulation establishment which is based on the interpretation of the Laws and Regulation, guidance related to the type of Laws and Regulations on regional policy regulatory in order to conduct regional government under its authority is needed to be given.

\section{ACKNOWLEDGMENT}

On this occasion, we would like to thank LPPM UNUD through the 2018 PNBP fund for this research to be carried out well and the Provincial Government of Bali. Thanks are also conveyed to the research team regarding legal hermeneutics in the preparation of Perkada in Bali Province

\section{REFERENCES}

[1] Andi Pitono, 2011, Disertasi: Implementasi Kebijakan Pendelegasian Wewenang Dari Bupati Kepada Camat Bidang Pengembangan Otonomi Daerah Dan Kependudukan (Studi Tentang Pendelegasian Wewenang Dari Bupati Kepada Camat Di Kabupaten Bandung), Universitas Airlangga, Surabaya.

[2] Bayu Dwi Anggono, 2014,Disertasi:Perkembangan Pembentukan Undang-Undang di Indonesia, Universitas Indonesia, Jakarta.

[3] C. Van Der Vlies, 2005, Buku Pegangan Perancang Peraturan Perundang-undangan (Handboek Wetgeving), Direktorat Jenderal Peraturan Perundang-undangan Departemen Hukum dan Hak Asasi Manusia RI, Jakarta.

[4] Charlie Rudayat, 2014, Kamus Hukum, Pustaka Mahardika, Bandung.

[5] Febrian, 2004, Disertasi : Hierarki Aturan Hukum di Indonesia, Universitas Airlangga, Surabaya. 
[6] Jazim Hamidi, 2005, Hermeneutika Hukum: Teori Penemuan Hukum Baru dengan Interpretasi Teks, UII Press, Yogyakarta.

[7] Jan Gijsels, Mark Van Hocke (terjemahan B. Arief Sidharta) Apakah Teori Hukum Itu ?, Laboratorium Hukum Universitas Parahyangan Bandung.

[8] J.J.H. Bruggink, 1996, Refleksi Tentang Hukum, Citra Adytia Bhakti, Bandung.

[9] Max BoliSabon, 1994, Ilmu Negara Buku Panduan Mahasiswa, Gramedia Pustaka Utama.

[10] Marcus Lukman, 1996, Disertasi : Eksistensi Peraturan Kebijaksanaan Dalam Bidang Perencanaan dan Pelaksanaan Rencana Pembangunan Di Daerah Serta Dampaknya Terhadap Pembangunan Hukum Tertulis, Unpad, Bandung.

[11] Philipus M Hadjon \& Tatiek Sri Djatmiati, 2014, Argumentasi Hukum, Gadjah Mada University Press.

[12] P.P.Craig, 1994, Administrative Law, London Sweet, and Maxwell.

[13] Ridwan, 2013, Diskresi \& Tanggung Jawab Pemerintah, Universitas Airlangga, Surabaya.

[14] Satjipto Raharjo, 2000, Ilmu Hukum, Citra Aditya Bakti, Bandung.

[15] Sukardi, 2009, Wewenang Pembatalan Perda by Sukardi from Program Doktor UNAIR Surabaya

[16] Theo Huijbers, 1982, Filsafat Hukum Dalam Lintasan Sejarah, Yayasan Kanisius Yogyakarta. 